\title{
A CRITIQUE OF THE VALUE INTERACTION DEBATE
}

\section{Rafe McGregor}

The purpose of this paper is to show that the value interaction debate is deeply flawed and constitutes a superficial analysis of the relationship between morality and art. I introduce the debate, which concerns whether a moral defect in a work of art is (also) an aesthetic defect, in $\S 1 . \S 2$ establishes the vagueness of two key terms in the discussion, moral defects and aesthetic defects. In $\S 3$ I introduce the naive assumption-uninteresting claim disjunction, identifying five of the six approaches as demonstrating a fundamental naivety about the relationship between morality and narrative art. I show, in $\S 4$, that four of the six are philosophically uninteresting as they offer an incomplete - and ultimately unsatisfactory explanation of this relationship. In $\S 5$ I discuss the quantity and quality of examples employed in the debate, many of which are non-canonical, and some of which are entirely inappropriate. I conclude by recommending a reorientation of the debate to focus on the underlying question of whether the characteristically artistic value is finally or instrumentally valuable.

\section{The Value Interaction Debate}

I have derived value interaction from Robert Stecker's analysis of the debate, ${ }^{1}$ and the value interaction debate is the most recent instantiation of philosophical interest in the relationship between the moral value and the aesthetic value of works of art. There were several notable

\footnotetext{
1 “The Interaction of Ethical and Aesthetic Value," British Journal of Aesthetics 45 (2005), 138-150: 138.
} 
precursors to the contemporary discussion, ${ }^{2}$ but the value interaction debate was initiated by Noël Carroll with "Moderate Moralism" in $1996,{ }^{3}$ followed closely by contributions from Daniel Jacobson ${ }^{4}$ and Matthew Kieran. ${ }^{5}$ The debate is concerned with the interaction of moral value and aesthetic value in art, understood in terms of the relationship between moral defects and merits on the one hand, and aesthetic defects and merits on the other. ${ }^{6}$ I shall characterise the discussion in terms of the following pair of statements:

(1) A moral defect in a work of art is (also) an aesthetic defect.

(2) A moral merit in a work of art is (also) an aesthetic merit.

Broadly speaking, a moralist position supports (1) and (2) - and thus value interaction - and an autonomist position denies (1) and (2), holding that the two types of value are independent of each other. The focus of the debate has been on (1), and I shall follow suit in this paper.

The dispute has primarily been concerned with moral and aesthetic defects in works of narrative art, with examples typically drawn from literature and film. A.W. Eaton's initial contribution to the debate, on the relation between the moral defects and aesthetic defects of Titian's Rape of Europa, is a notable exception, but her discussion of the different ways in which works of pictorial art and literary art call for affective responses confirms the

\footnotetext{
2 The following three are particularly relevant: Kendall Walton, "Morals in Fiction and Fictional Morality I," Proceedings of the Aristotelian Society, Supplementary Volumes 68 (1994), 27-50; Michael Tanner, "Morals in Fiction and Fictional Morality II," Proceedings of the Aristotelian Society, Supplementary Volumes 68 (1994), 51-66; and Peter Lamarque, "Tragedy and Moral Value," Australasian Journal of Philosophy 73 (1995), 239249.

3 "Moderate Moralism," British Journal of Aesthetics 36 (1996), 223-238.

4 "Sir Philip Sidney's Dilemma: On the Ethical Function of Narrative Art," The Journal of Aesthetics and Art Criticism 54 (1996), 327-336; "In Praise of Immoral Art," Philosophical Topics 25 (1997), 155-199.

5 “Art, Imagination, and the Cultivation of Morals," The Journal of Aesthetics and Art Criticism 54 (1996), 337351.

${ }^{6}$ The value interaction debate in general, and Carroll's and A.W. Eaton's respective approaches in particular, are also related to the philosophical concern with imaginative resistance. Imaginative resistance is derived from Hume's "Of The Standard of Taste" (1757), and was revisited in the exchange between Walton and Tanner (see fn.2) and Richard Moran's “The Expression of Feeling in Imagination” (The Philosophical Review 103 [1994], 75-106). The debate was popularised by Tamar Szabó Gendler's “The Puzzle of Imaginative Resistance” (The Journal of Philosophy 97 [2000], 55-81) and the numerous responses it provoked. Although there are flaws with the concept of imaginative resistance as advanced by Hume, Walton, Tanner, Moran, and Gendler, this would be the subject of another paper.
} 
limitation of my argument in this paper to narrative art (which I acknowledge in $\S 6){ }^{7}$ I shall also restrict my critique to Carroll's moderate moralism and the following five systematic approaches: Berys Gaut's ethicism, Eaton's robust immoralism, Kieran's cognitive immoralism, Jacobson's anti-theory, and James Anderson and Jeffrey Dean's moderate autonomism. I summarise these positions as follows:

(1) Moderate Moralism: a moral defect is sometimes an aesthetic defect in a work of art. $^{8}$

(2) Ethicism: a moral defect is always a pro tanto aesthetic defect in a work of art. $^{9}$

(3) Moderate Autonomism: a moral defect is never an aesthetic defect in a work of art. $^{10}$

(4) Robust Immoralism: a moral defect is sometimes an aesthetic merit in a work of art. $^{11}$

(5) Cognitive Immoralism: a moral defect is sometimes an aesthetic merit in a work of art due to the cognitive value of that defect. ${ }^{12}$

(6) Anti-Theory: there is no systematic relation between moral value (defects and merits) and aesthetic value (defects and merits) in works of art. ${ }^{13}$

\footnotetext{
7 "Where Ethics and Aesthetics Meet: Titian's Rape of Europa," Hypatia 18 (2003), 159-188: 165-166. Eaton and I disagree on the nature of the respective affective responses: she suggests that literary works make propositional calls for affective responses (which I deny in $\S 3$ ), whereas I think it more likely that pictorial works are accurately characterised in this way (as discussed in §6).

${ }^{8}$ Carroll, "Moderate Moralism." Carroll has been the most prolific contributor to the debate, publishing ten further papers from 1998 to 2013. Considerations of space aside, I do not need to address each of these as his support of moderate moralism has remained unchanged.

${ }^{9}$ Gaut, "The Ethical Criticism of Art," in Aesthetics and the Philosophy of Art, eds. Peter Lamarque \& Stein Haugom Olsen (Oxford: Blackwell, 2008 [1998]), 283-294.

${ }^{10}$ Anderson \& Dean, "Moderate Autonomism," British Journal of Aesthetics 38 (1998), 150-166.

${ }^{11}$ Eaton, "Robust Immoralism," The Journal of Aesthetics and Art Criticism 70 (2012), 281-292.

${ }^{12}$ Kieran, "Forbidden Knowledge: The Challenge of Immoralism," in Art and Morality, eds. José Luis Bermúdez \& Sebastian Gardner (London: Routledge, 2003), 56-73. Kieran's initial contributions to the debate, "Art, Imagination, and the Cultivation of Morals" and "In Defence of the Ethical Evaluation of Narrative Art" (British Journal of Aesthetics 41 [2001], 26-38) were as a moralist, a position he termed 'Most Moderate Moralism' ("Ethical Evaluation of Narrative Art," 33). I shall not discuss most moderate moralism in this paper.
} 
My claim is that all six of these positions, as well as the numerous fine-tunings thereof, ${ }^{14}$ are deeply flawed. Although I conclude with a recommendation for the future of the debate, this paper is primarily critical, demonstrating three significant failings in the six theses: vague terminology; a disjunctive trap the result of which is that all six are either naive, uninteresting, or both; and examples which provide evidence of the superficiality of the debate.

\section{Vague Terminology}

All seven authors employ the terms moral defect and aesthetic defect, but only Eaton offers a definition of the former. She identifies five ways in which a work of art can be judged as ethically defective: subject matter represented, character of the artist, methods of production, behavioural consequences, and vision or perspective. ${ }^{15}$ Eaton restricts her interest to the last of these, the 'work's evaluative attitude toward diegetic elements" ${ }^{16}$ and then narrows her focus further, to the moral defect of the 'rough hero'. ${ }^{17}$ In the genre of the rough hero, readers and viewers are invited both to sympathise with a morally reprehensible character and to despise his or her enemies, and the invitation to adopt this perspective is a moral defect. ${ }^{18}$ I shall have more to say about Eaton's rough heroes in general and her specificity in particular in the next section. Unfortunately there is no such specification from any of the

\footnotetext{
${ }^{13}$ Jacobson, "Ethical Criticism and The Vice of Moderation," in Contemporary Debates in Aesthetics and the Philosophy of Art, ed. Matthew Kieran (Oxford: Blackwell, 2006), 342-355.

${ }^{14}$ While there have only been two books engaging directly with the debate (Gaut's Art, Emotion, and Ethics [Oxford: Oxford University Press, 2007] and Elisabeth Schellekens' Aesthetics and Morality [London: Continuum, 2007]), there has been an abundance of individual papers and replies in the last seventeen years. Since 2000, the debate has expanded beyond aesthetics journals and contributions have appeared in: Ethics, Hypatia, The Philosophical Forum, Philosophy Compass, Philosophia, the South African Journal of Philosophy, The Journal of Value Inquiry, The Philosophical Quarterly, Ratio, and Ethical Perspectives. The most recent contribution is by Alessandro Giovannelli: "Ethical Criticism in Perspective: A Defense of Radical Moralism," The Journal of Aesthetics and Art Criticism 71 (2013), 335-348.

15 "Where Ethics and Aesthetics Meet," 164-165; "Robust Immoralism," 282.

16 "Robust Immoralism," 282.

${ }^{17}$ Ibid., 283.

${ }^{18}$ Ibid., 285.
} 
other authors. Numerous examples of moral defects are provided-racism in Triumph of the Will, homophobia in Pulp Fiction, and sadism in de Sade - but none of the other approaches include an explanation of what, exactly, a moral defect in a work of art is. As Eaton is well aware, the question is by no means simple. Is, for example, the repeated use of the word "nigger" a moral defect in Heart of Darkness? Is the graphic violence in Straw Dogs a moral defect? What about the moral ambiguities of Lolita and Unforgiven - are these moral defects? The answers are far from clear. I believe this vagueness is related to my criticism of naivety, which I discuss in $\S 3$, and only Eaton escapes blame for employing at least one vague term.

With regard to aesthetic defects, only Carroll and Gaut offer definitions: the problem is particularly pertinent for the two moralists, as they are attempting to prove that a moral defect 'counts as ${ }^{19}$ an aesthetic defect or 'counts against' ${ }^{20}$ aesthetic value. ${ }^{21}$ Eaton once again escapes censure as although she does not define an aesthetic defect in her argument for robust immoralism, she is concerned with aesthetic merits rather than defects. She defines an aesthetic merit in terms of a work's effect on its audience in (i) overcoming imaginative resistance to sympathising with immoral characters and (ii) producing a state of compelling ambivalence. ${ }^{22}$ For Carroll, an aesthetic defect is a flaw which 'actually deters the response to which a work aspires. ${ }^{23}$ His example is tragedy, and he notes that a tragic hero must have a particular type of character (admirable, but with a fatal flaw); 'the tragedy will fail on its

\footnotetext{
${ }^{19}$ Carroll, "Moderate Moralism," 234.

${ }^{20}$ Gaut, "Ethical Criticism of Art," 182.

${ }^{21}$ Again, there is vagueness in the exact relation proposed. In "Ethics and Aesthetics: Replies to Dickie, Stecker, and Livingston", Carroll uses the term 'constitutes', but then suggests a relation of identity on the next page (British Journal of Aesthetics 46 [2006], 82-95: 85). As the latter is implausible, I shall take the relation proposed by the moralists to be one of constitution, i.e. a moral defect either always (Gaut) or sometimes (Carroll) constitutes an aesthetic defect in a work of art.

22 "Robust Immoralism," 287-288. Eaton does in fact define an aesthetic defect in "Where Ethics and Aesthetics Meet" (175-176), but I think there is a tension between her positions on Hume in her two contributions to the debate. I do not have space to discuss both papers in detail and shall focus on "Robust Immoralism".

23 “Moderate Moralism," 234.
} 
own terms - terms internal to the practice of tragedy - when the characters are of the wrong sort. ${ }^{24}$ Carroll's definition is similar to Gaut's: 'a defect in the work qua work of art', ${ }^{25}$ an example of which is a work prescribing an unmerited response, which means 'it has failed in an aim internal to it' ${ }^{26}$ Gaut begins his explanation of a merited response by mentioning the potential failures of horror, comedy, and thriller fiction - e.g., thrillers that do not thrill which mirrors Carroll's appeal to a tragedy failing on its own terms. ${ }^{27}$

Carroll subsequently criticises Anderson and Dean for setting out his argument in terms of genre:

I am not sure why they insist on talking about genres here, since it will be an aesthetic defect of the work if it fails to secure its aims, whether or not those aims are genre specific. $^{28}$

Anderson and Dean have identified genre as significant because a tragedy failing to be tragic and a comedy failing to be funny are the examples that Carroll and Gaut have used to make their readers more receptive to their respective arguments. The problem is that a work of horror which fails to frighten seems completely different to the kind of failure envisaged by Carroll and Gaut in the immorality of works such as Pulp Fiction and Juliette, or Vice Amply Rewarded. Anderson and Dean draw attention to the fact that the most convincing examples are failures in genre works as it is relatively simple to identify whether a work of genre has failed or succeeded. There is a sleight of hand at play here because - if Carroll and Gaut are correct about tragedy and comedy - then the ethical equivalent will be didactic narratives; for example, if Harriet Beecher Stowe's Uncle Tom's Cabin; or, Life Among the Lowly failed to show that slavery was immoral. In an overtly ethical work, it seems plausible to regard a

\footnotetext{
${ }^{24}$ Ibid., 232.

25 "Ethical Criticism of Art," 194.

${ }^{26}$ Ibid.

${ }^{27} \mathrm{Ibid}$

28 "Moderate Moralism versus Moderate Autonomism," British Journal of Aesthetics 38 (1998), 419-424: 423.
} 
failure to make a convincing case for the approved moral stance as a failure of the work on its own terms. ${ }^{29}$

The aesthetic failure that Carroll sees in Pulp Fiction and Gaut in Juliette is, however, the successful uptake of a morally defective perspective. If, for example, Juliette invites arousal or amusement in response to sexual cruelty and readers are indeed aroused or amused, then this success is a failure of the work on its own terms. Carroll explains this apparent contradiction by using the example of a war-time film that depicts the enemy as sub-human, claiming that in such films 'the moral flaws sit like time-bombs, ready to explode aesthetically once morally sensitive viewers, listeners and readers encounter them.' ${ }^{30}$ Gaut's explanation employs his 'cognitive-affective view of art': by promoting an ethically reprehensible attitude, the work advances an immoral perspective as a moral one and therefore commits an epistemic error by showing falsity as truth. ${ }^{31}$ But doesn't the successful uptake of an immoral perspective point to either a morally corrupt audience or - more likely - the skilful employment of aesthetic devices to portray the immorality as attractive in some way? This is of one of Plato's moral objections to tragic poetry, his concern with its power to corrupt audiences. ${ }^{32}$ It is also difficult to understand how de Sade - as a writer of fiction can be regarded as aiming for truth in his work. The suggestion that he has failed by misrepresenting immorality as moral truth recalls Plato's epistemic distrust of poetry, the basis of which was that poets should not be addressing audiences because they are not experts and are therefore likely to make factual errors. ${ }^{33}$ In short, no satisfactory reason is offered for

\footnotetext{
${ }^{29}$ Carroll admits as much in his discussion of realist novels. See: "Literary Realism, Recognition, and the Communication of Knowledge," in Art in Three Dimensions, (Oxford University Press, 2012 [2010]), 458-472. 30 "Moderate Moralism," 234.

31 "Ethical Criticism of Art," 195.

${ }^{32}$ Republic, trans. G.M.A. Grube \& C.D.C. Reeve, in Plato: Complete Works, ed. John M. Cooper (Indianapolis: Hackett, 1997), 595b:3-6.

${ }^{33}$ Apology, trans. G.M.A. Grube \& C.D.C. Reeve, in Plato: Complete Works, ed. John M. Cooper (Indianapolis: Hackett, 1997), 22:b4-c6.
} 
why the (moral) desirability of a work's aims should be considered when judging the (aesthetic) success of the work on its own terms.

The real problem of vagueness is revealed in Carroll's reply to George Dickie. Carroll states that 'according to Dickie, the concept of the aesthetic should be restricted to the kinds of properties isolated by Frank Sibley.' 34 Carroll subsequently employs the term 'formal defects' for aesthetic defects when describing a hypothetical painting of Hitler entitled Saviour. ${ }^{35}$ The problem is that if aesthetic defects are formal defects, then they will, in his own example, be defects of properties such as colour, shape, scale, contrast, harmony, and proportion. In literary works, formal defects will typically be concerned with morphology, syntax, meter, and tropes. Thus, if aesthetic defects are identical - or even similar - to formal defects, it seems as if they will be entirely distinct from moral defects in the characters, events, or perspective of a novel. In order to avoid this objection, Carroll reiterates his functional account of form as 'the ensemble of choices intended to realize the point or purpose of the artwork. ${ }^{36}$

In employing this broader conception, however, he leaves himself open to the very same over-inclusivity criticism he levels at Gaut: 'Gaut's demarcation of the aesthetic is highly revisionist and, with justice, the moderate autonomist may charge that it has been rigged against him. ${ }^{37}$ In his initial paper, Gaut identifies aesthetic value with artistic value, 'the value of an object qua work of art', which includes 'beauty', 'cognitive insight' and an 'articulated expression of joy', and excludes instrumental values such as 'investment value'

\footnotetext{
34 "Replies to Dickie, Stecker, and Livingston," 83.

${ }^{35}$ Ibid., 85.

${ }^{36}$ Philosophy of Art: A Contemporary Introduction (London: Routledge, 1999), 143.

${ }^{37}$ Carroll, "At the Crossroads of Ethics and Aesthetics," Philosophy and Literature 34 (2010), 248-259: 257.
} 
and 'value as status symbols'. ${ }^{38}$ Subsequently, he addresses five objections to this view, ${ }^{39}$ and then states:

We have identified the (wide) aesthetic properties of artworks with their artistic properties, the properties that make something valuable qua art, and so have given an explanation for the otherwise mysterious diversity of aesthetic properties. ${ }^{40}$

The problem is now obvious: moral attitude ${ }^{41}$ should be listed alongside cognitive insight above as an artistic (and therefore aesthetic) value. And if moral value is a constituent of aesthetic value, then the claim that a moral defect is an aesthetic defect is a tautology: if an aesthetic defect is any defect in the content of the work of art, then it is obvious that a moral defect - just like a cognitive defect - can be an aesthetic defect. Both solutions to the problem of vagueness are therefore fatal for the moralist positions. The crucial issue in the value interaction debate is whether a moral defect $x$ can constitute an aesthetic defect $y$. With the exception of Eaton, the participants either (i) fail to define $x$ and $y$ or (ii) fail to define $x$ and define $y$ in an unsatisfactory manner, with the result that the basis of the majority of the debate is vague.

\section{The First Disjunct: Naive Assumptions}

My second proposal is that each of the six approaches is guilty of either naive assumptions, uninteresting claims, or both. The value interaction debate provides evidence for the following three relations between morality and literature:

(1) The work manifests a moral attitude, which is described in terms of a prescribed response for the reader. Gaut states: 'the novel does not just

\footnotetext{
38 "Ethical Criticism of Art," 183.

${ }^{39}$ Art, Emotion and Ethics (London: Oxford University Press, 2009 [2007]), 34-40.

40 Ibid., 40.

${ }^{41}$ Gaut describes the moral attitude of a work in terms of its prescribed response, which I discuss in $\S 3$.
} 
present imagined events, it also presents a point of view on them, a perspective in part constituted by actual feelings, emotions, and desires that the reader is prescribed to have towards the merely imagined events. ${ }^{42}$

(2) The work prompts an attitudinal response: 'A work prescribes an attitude toward diegetic elements by imbuing them with traits that are prompts for the attitude in question, where a prompt is a feature (or set of features) that aims to stimulate and elicit a particular type of attitude under appropriate circumstances. $^{43}$

(3) The work contributes to - or detracts from - moral understanding by suggesting a moral perspective. Carroll uses Pulp Fiction as an example of narrative art and notes that it is morally defective because it 'suggests that homosexual rape is much worse than murder'. ${ }^{44}$

Beginning with (1), it is not obvious that a work which is not overtly didactic does prescribe a moral perspective or response, as Gaut states. To use his own example, what moral response is prescribed by Paradise Lost? To state that the poem prescribes sympathy for Satan or the recognition of Adam as a tragic hero is to over-simplify the complexity of its moral content. Eileen John maintains that Gaut, Carroll, and Jacobson are all guilty of naivety in over-simplifying prescribed responses. ${ }^{45}$ Like Gaut and Carroll, Jacobson accepts the assumption that a failure to elicit the requisite (moral or other) response is an aesthetic failure in a work of art. ${ }^{46}$ John claims that this type of uptake is not in fact needed. She uses several examples, one of which is Portrait of a Lady, a novel that endorses a choice of

\footnotetext{
42 "Ethical Criticism of Art," 289. The novel mentioned is Juliette.

43 "Robust Immoralism," 282.

44 "Moderate Moralism," 230.

45 "Artistic Value and Opportunistic Moralism," in Contemporary Debates in Aesthetics and the Philosophy of Art, ed. Matthew Kieran (Oxford: Blackwell, 2006), 331-341: 337.

46 "Immoral Art," 168; "The Vice of Moderation," 347.
} 
fidelity to a dreadful marriage over deserved personal happiness. John explains that in neither of her two readings did she agree with the heroine's choice (as sanctioned by the novel), but that the mismatch of prescribed and actual response did not prevent her from appreciating and enjoying the work. ${ }^{47}$ Nor is the mismatch an aesthetic flaw ${ }^{48}$ and the success of a work is not reliant upon uptake, but rather 'that we recognize what the sanctioned moral responses are, where that can be a relatively intellectual kind of recognition. ${ }^{49}$

If one considers the differences in morality over time and between cultures, one becomes aware of just how rare the kind of match Carroll, Gaut, and Jacobson assume is ever likely to occur. Hume ${ }^{50}$ was well aware of this problem in his attempt to establish an objective standard of beauty ("aesthetic value" in contemporary terms). He proposed that the standard of taste was the standard indicated by true judges, and identified a set of criteria for a true judge. He nonetheless noted that even amongst true judges there will be variation, because of the difference in their characters, and because of their preference for works from their own cultures. ${ }^{51}$ Where the difference in culture between work and critic concerns manners and customs, the true judge should make allowances for the difference in his evaluation, but where the difference concerns virtue and vice, the invitation to accept a vice as a virtue disfigures the work. ${ }^{52}$ Hume's mention of the likely lack of sympathy for Homer's 'rough heroes ${ }^{53}$ is the source of Eaton's name for the genre of narrative works she employs in her argument for robust immoralism and Hume's example serves both the eighteenth and twenty-

\footnotetext{
47 “Artistic Value and Opportunistic Moralism,” 334.

${ }^{48}$ Ibid., 334-335.

${ }^{49}$ Ibid., 337.

50 "Of the Standard of Taste," in David Hume: Essays, Moral, Political, and Literary (Indianapolis: Liberty Fund, 1987 [1757]), 226-249.

${ }^{51}$ Ibid., 243.

52 Ibid., 246. This claim by Hume is the origin of the imaginative resistance debate (see fn.6).

${ }^{53}$ Ibid.
} 
first century equally well. No one who does not endorse the ethics of the heroic society as depicted by Homer will meet the prescribed moral response - if, indeed, there is such a thing - of the Iliad or the Odyssey, but this has not prevented three millennia's worth of audiences appreciating and enjoying the works. The issue is not, for example, that I accept Odysseus as virtuous, but that I recognise he is virtuous in (the world of) the poem. John's conclusion is that:

Our responses should show that we grasp whatever counts as morally important, within the narrative, but not necessarily that we judge and feel in the way deemed appropriate by the work. ${ }^{54}$

Appreciation therefore requires grasping what is morally significant in the work rather than responding in a prescribed manner.

Eaton also employs the term "prescribe" in her description of the way in which a work prompts an attitudinal response in (2). Indeed, she offers an explicit answer to the question I posed above: Milton's Satan is a paradigmatic rough hero and Paradise Lost 'prescribes our wonder, reverential admiration, and respect for the grand but evil being. ${ }^{55}$ Eaton's prescription is, however, a misrepresentation which fails to account for either the subtlety of the work's moral content or the range of compelling interpretations of the poem, from Satan as a tragic hero to Satan as an arch-villain. Robust immoralism is a development of Eaton's initial argument for 'ethicism ${ }^{56}$ and the work of Jacobson and Justin D'Arms. ${ }^{57}$ As noted in $\S 2$, she distinguishes a genre of literary and cinematic works which are morally defective in inviting readers and viewers to sympathise with a variety of rough heroes, which she

\footnotetext{
54 “Artistic Value and Opportunistic Moralism," 338.

55 "Robust Immoralism," 284.

56 "Where Ethics and Aesthetics Meet," 159. Eaton refers to her position here as ethicism, but I think it is actually closer to moderate moralism in terms of the six positions I set out in $\S 1$.

${ }^{57}$ In particular: D'Arms \& Jacobson, "The Moralistic Fallacy: On the 'Appropriateness' of Emotions,"

Philosophy and Phenomenological Research 61 (2000), 65-90.
} 
catalogues according to the following types: admirable devils, glorified criminals, congenial murders, likeable sex criminals, sympathetic sadists, and appealing mean-spirited people. ${ }^{58}$ As also noted in $\S 2$, Eaton argues that the acceptance of the invitation to regard a rough character qua hero is not an aesthetic defect, but - contra Hume - an aesthetic merit. Her version of immoralism is "robust" because the aesthetic merit is in virtue of the moral flaw rather than derived from the cognitive value of the moral flaw.

Eaton distinguishes a rough hero from an anti-hero by means of five traits. Unlike the antihero, the rough hero is: (i) grievously and (ii) intrinsically immoral, (iii) remorseless, (iv) totally reprehensible, and (v) possessed of no virtue sufficient to redeem his or her vices. ${ }^{59}$ These character traits combine with narrative traits to prompt the particular response the work prescribes. The prescribed response is an evaluative attitude which Hume's terminology captures nicely: the protagonist is both morally hateful (i.e., rough) and sympathetic (i.e., heroic). ${ }^{60}$ This prescription is more specific than that envisaged by Gaut, Carroll, and Jacobson and the specificity makes Eaton more susceptible to the mismatch which evinces the lack of sophistication with which I am concerned. Eaton's comprehensive list of rough heroes is replete with mismatches, but I shall ignore the non-canonical examples that I target in $§ 5$ (such as de Sade's several protagonists and American Psycho's Patrick Bateman) and focus on two uncontroversially ${ }^{61}$ artistic works.

My interpretation of Lolita is completely at odds with Humbert Humbert as a 'likeable sex criminal' and I find little evidence for Eaton's claim that his 'intelligence, wit, and rhetorical

\footnotetext{
58 "Robust Immoralism," 284.

${ }^{59}$ Ibid.

${ }^{60}$ Ibid., 285.

${ }^{61}$ Subject to the reservation I express about the use of all works of cinematic art as examples in $\S 5$.
} 
gifts lure us in to liking and sympathizing with him and condoning his actions' in the novel. ${ }^{62}$ Humbert is certainly amusing, both intentionally in the humour of his narration and unintentionally in the desperation of his desire, but if Nabokov is prescribing sympathy for him, ${ }^{63}$ then my response is an exemplary mismatch. Here is one of several passages which account for my failed uptake:

the thought that around 1950 I would have to get rid somehow of a difficult adolescent whose magic nymphage had evaporated - to the thought that with patience and luck I might have her produce eventually a nymphet with my blood in her exquisite veins, a Lolita the Second, who would be eight or nine around 1960, [...] indeed, the telescopy of my mind, or un-mind, was strong enough to distinguish in the remoteness of time [...] practising on supremely lovely Lolita the Third the art of being a granddad. ${ }^{64}$

Humbert is no rough hero, but a villain, and a particularly despicable one. At the opposite extreme, my interpretation of Unforgiven is that William Munny is a reformed villain, whose virtues outweigh his vices, and who temporarily returns to his previous way of life with great regret. Munny is grievously immoral, but the coincidence of circumstances which causes him to accept the commission for murder draw attention to the kind of moral dilemma - let my children starve or kill for money - which would not be appropriate to the intrinsically immoral rough hero. Furthermore, Munny's redemption is emphasised in the final shot of the film, where he is ironically described as 'a known thief and murderer, a man of notoriously vicious and intemperate disposition. ${ }^{65}$

\footnotetext{
62 "Robust Immoralism," 284.

${ }^{63}$ Which I very much doubt, as I reiterate in $\S 5$.

${ }^{64}$ Vladimir Nabokov, Lolita (London: Penguin, 1997 [1955]), 171-172.

${ }^{65}$ Unforgiven, directed by Clint Eastwood (1992; Burbank, CA: Warner Bros., 2009), DVD.
} 
My point is not that Eaton's list is erroneous - that she should replace Lolita with James Ellroy's White Jazz or Unforgiven with Matthew Vaughn's Layer Cake - but that in neither case did my imaginative engagement involve sympathy for a character who matched her five criteria. Eaton notes that a 'work can prompt an attitudinal response without actually succeeding in producing that response', ${ }^{66}$ but John's critique is nonetheless applicable. I do not regard myself as having failed to understand, enjoy, and appreciate either Lolita or Unforgiven; nor do I regard my lack of uptake of Humbert as heroic and Munny as rough as aesthetic defects in the works. Eaton's assumption that works in the rough heroes genre prompt a particular attitudinal response is naive because the match between prompt and response is neither a sufficient nor a necessary condition for appreciation. She has identified an interesting genre of morally problematic narrative art, but she has also misrepresented the relationship between moral and aesthetic value within that genre.

Regarding (3), the term suggest is vague. To suggest can mean to propose or to bring to one's mind indirectly. The former is too strong for moral perspectives in literature; the latter too weak. In Carroll's cinematic example, it is not obvious that Pulp Fiction proposes homophobia, but it may bring many different ideas to mind indirectly. If the method is indirect, then it seems as if what is brought to mind will depend more upon the viewer than the work. Carroll's cinematic example is paradigmatic of the naivety of which I am accusing everyone in the debate with the exception of Kieran. Carroll states that Pulp Fiction has a flawed moral perspective because it suggests that death is preferable to homosexual rape. First, it is far from clear that this is a moral flaw: when one considers any great mental and physical harm to a human being, it seems grossly insensitive to claim that - ceteris paribus there is a moral obligation upon the individual to choose to endure the harm rather than die. I

66 “Robust Immoralism,” 282. 
am sure Carroll would agree that when an individual is faced with harms such as rape or torture, one should respect the individual's choice, if he or she has a choice available. Presumably Carroll's point is that the suggestion that death is preferable to homosexual rape is homophobic, and that a film which has a homophobic moral perspective is morally flawed. This is far more compelling, but what evidence is there for the homophobia?

Carroll does not provide any, so I must assume he is referring to the scene in which Marsellus (a crime boss played by Ving Rhames) and Butch (a professional boxer played by Bruce Willis) have been abducted at gunpoint by what appears to be a pair of homosexual serial killers. Butch manages to break free and has the opportunity to either escape or rescue Marsellus from rape and murder. Even though Marsellus has just attempted to kill Butch, Butch decides to go to his assistance. Butch intervenes while Marsellus is being raped, killing one of the abductors while Marsellus wounds the other. In gratitude, Marsellus agrees to settle their differences on the conditions that Butch does not disclose the abduction and also leaves the city. The fact that Marsellus, a gangster without respect for human life or dignity - and who is looking forward to torturing the surviving abductor to death - is homophobic (if this is actually what the scene shows) hardly constitutes a homophobic perspective on the part of the film. Nor can the decision of Butch - probably the only major character in the film who has any recognisable system of values - to aid an enemy who is facing prolonged sexual and physical torture be construed as homophobic.

The problem with Carroll's interpretation is that it over-simplifies the moral content of the film. Carroll derives a proposition, homosexual rape worse than death, from the above scene (or perhaps from elsewhere in the film), finds evidence of homophobia in the proposition, and evaluates the work as homophobic and therefore morally defective. His view assumes that 
the moral perspective in or of the work can be assessed, categorised, and judged in a similar way to a philosophical argument. The moral content (or part thereof) of Pulp Fiction has been stated as a proposition, which is questionable in itself, and that proposition has then been evaluated in isolation from the narrative from which it has been extracted. The naivety is reminiscent of the way in which critics speak of the "message" of a work as if the proposition power corrupts, absolute power corrupts absolutely states something significant about Macbeth .

In identifying four types of all-things-considered judgements of works of art, Anderson and Dean demonstrate an even more naive approach to the moral content of narratives, writing of 'the moral flaw' ${ }^{67}$ and 'the moral values' ${ }^{68}$ as measured against aesthetic and other merits in the work. These naive assumptions misrepresent the moral significance of works of narrative art. As Kieran noted while still a moralist, works of art are valuable for 'their exploration of our values and commitments' rather than providing evidence for the correct moral theory. ${ }^{69}$ The problem is related to the vagueness of moral defects identified in $\S 2$ : only one person involved in the debate is explicit about what exactly a moral defect in a work of narrative art is, and all except for Kieran appear to make naive assumptions about the moral content of narrative art.

\section{The Second Disjunct: Uninteresting Claims}

I have not accused Kieran of naivety, but he and Jacobson are both guilty of making philosophically uninteresting claims, understood as offering an incomplete and unsatisfactory explanation of the relationship between morality and narrative art. Kieran's cognitive

\footnotetext{
67 "Moderate Autonomism," 164.

${ }^{68}$ Ibid., 166.

69 "Art, Imagination, and the Cultivation of Morals," 345.
} 
immoralism is a development of his initial view of art as an exploration of moral values and commitments, ${ }^{70}$ and Jacobson's acquaintance model, where narrative art functions ethically by providing imaginative acquaintance with different ethical perspectives. ${ }^{71}$ Kieran defines his position as follows:

Immoralism is the claim that a work's value as art can be enhanced in virtue of its immoral character. Cognitive immoralism holds that this is so because imaginatively experiencing morally defective cognitive-affective responses and attitudes in ways that are morally problematic can deepen one's understanding and appreciation. ${ }^{72}$ A moral defect is sometimes an aesthetic merit, based on the cognitive value of that defect. A moral defect can also be an aesthetic defect, and moral merits can be either aesthetic merits or aesthetic defects. Cognitive immoralism constitutes a successful refutation of ethicism (where a moral defect is always an aesthetic defect), but it is reliant upon the cognitive value of art. $^{73}$

Jacobson's anti-theory is entirely compatible with cognitive immoralism, as he notes, although he also notes his reluctance to commit to the cognitive view of aesthetic value advanced by Kieran. ${ }^{74}$ Despite Jacobson's denials, ${ }^{75}$ anti-theory is equally consistent with moderate moralism. ${ }^{76}$ Consider the following summary:

(1) A moral defect can be an aesthetic defect and a moral merit can be an aesthetic merit (moderate moralism).

\footnotetext{
${ }^{70}$ Ibid.

71 “Sir Philip Sidney's Dilemma," 333.

72 "The Challenge of Immoralism," 72.

73 There are several other problems with cognitive immoralism which I do not have space to address, including the instrumentalism to which Carroll alludes in "Art and Ethical Criticism: An Overview of Recent Directions of Research" (Ethics 110 [2000], 350-387: 380-381) and John in "Artistic Value and Opportunistic Moralism" (336).

74 "The Vice of Moderation," 353.

75 Ibid., 344.

${ }^{76}$ Stecker has a stronger stance, maintaining that: 'If immoralism is wrong, the anti-theoretical view at best devolves into moderate moralism' ("Immoralism and the Antitheoretical View," British Journal of Aesthetics 48 [2008], 145-161: 146).
} 
(2) A moral defect can be an aesthetic merit (cognitive immoralism).

(3) There is no systematic relation between moral defects and merits and aesthetic defects and merits (anti-theory).

The three claims are clearly compatible and although they all maintain that aesthetic and moral evaluations (can) interact and influence one another, none propose any necessary relation between the spheres of value. Notwithstanding his 'antitheoretical position', ${ }^{77}$ Jacobson's approach is the most comprehensive of the three, all of which can be summarised as: there is no systematic relation between moral defects and merits and aesthetic defects and merits. This claim provides a limited explanation of the relationship between morality and narrative art, but the problem for the three approaches is that they are all in fact committed to the an even weaker claim: a moral defect or merit can either decrease or increase the aesthetic value of a work of art, or have no effect at all. When one takes the terminological vagueness of the debate into account - recall that none of these authors have defined "moral defect" (or merit) - the statement is ultimately lacking in philosophical interest.

Returning to Gaut on aesthetic defects as described in $\S 2$, if his claim is indeed a tautology, then ethicism is also guilty of making an uninteresting claim: if an aesthetic defect is any defect in the content of a work of art, then it is an obvious truth that a moral defect is also an aesthetic defect. In $\S 1$, I identified cognitive immoralism as claiming that a moral defect is sometimes an aesthetic merit in a work of art due to the cognitive value of that defect.

Although Kieran presents his new theory in the context of the value interaction debate ${ }^{78}$ and employs the terms 'aesthetic defect' and 'aesthetic virtue', ${ }^{79}$ cognitive immoralism explains instances where 'the immoral character of the work turns out to be an artistic virtue rather

\footnotetext{
77 "The Vice of Moderation," 353.

${ }^{78}$ He begins "The Challenge of Immoralism" with a discussion of Carroll and Gaut (56-58) and then discusses Jacobson (61-62).

${ }^{79}$ For example, "The Challenge of Immoralism," 62.
} 
than a vice' ${ }^{80}$ Strictly speaking, therefore, his claim is: a moral defect can be an artistic merit. It is not clear whether Kieran is employing artistic as identical with aesthetic, in the same way as Gaut; if so, he is subject to the objection to which I have just alluded. ${ }^{81}$ It is clear, however, that - like Gaut - Kieran regards cognitive insight as a constituent of artistic/aesthetic value: 'the value of art, at least in part, is a function of the ways in which a work may deepen our understanding and appreciation. ${ }^{82}$ His claim might therefore be more accurately described as: a moral defect can be a cognitive merit in a work of art. Such a claim is of only tangential relevance to the focus of the debate, which is the relationship between moral value and aesthetic value. All six positions in the debate therefore fall into at least one of the disjuncts identified: there is evidence that Gaut, Carroll, Eaton, Jacobson and Anderson and Dean make naive assumptions; and evidence that Kieran, Jacobson, Carroll, and Gaut make uninteresting claims.

\section{Exemplo Ducemus?}

Kieran was the first to note the disproportionate quantity of examples in the value interaction debate, ${ }^{83}$ and Jacobson points to the controversy associated with 'tally arguments' as the reason for the lack of counter-examples to moralism and autonomism in his anti-theoretical work. ${ }^{84}$ I agree with Kieran's observation that one theory's example is often another theory's counter-example, but the most obvious problem is that the most frequently cited example,

\footnotetext{
80 "Art, Morality, and Ethics: On the (Im)Moral Character of Artworks and Inter-Relations to Artistic Value," Philosophy Compass 1/2 (2006), 129-143: 138.

${ }^{81}$ Kieran only discusses aesthetic value as distinct from artistic value in one paper, but he does not explain the relationship between them. See: "Emotions, Art and Immorality," in The Oxford Handbook of Philosophy of Emotion, ed. Peter Goldie (Oxford: Oxford University Press, 2010), 681-703.

82 "The Challenge of Immoralism," 58.

${ }^{83}$ Ibid., 60.

84 "The Vice of Moderation," 353.
} 
Triumph of the Will, is largely irrelevant to the debate. Although he discusses the film numerous times, Carroll is aware that it is far from paradigmatic:

Personally, I have always found the proposition that Triumph of the Will is an aesthetically good film problematic. Seen in its entirety and not in the edited versions that are usually screened, it is immensely boring, full of tedious Nazi party speeches. ${ }^{85}$ The same criticism could be made of the edited version for the same reason: it is shot through with political speeches which - setting their moral repugnance aside - are not poetic in any sense of the term. This is because whether or not one maintains that Triumph of the Will is a work of art, it is also a work of propaganda and its aesthetic properties are all carefully tailored to promote the policies and ideology of National Socialism. Mary Devereaux notes Leni Riefenstahl's denial that the work was propaganda, her claim to have been primarily motivated by aesthetic concerns, ${ }^{86}$ but the denial is as disingenuous as it is prudent.

I do not have space to discuss the phenomenon of didacticism in narrative art, suffice to say that there is - at least - a tension between overt didacticism and value qua art. My view is that few overtly didactic works will qualify as literary or cinematic art and those that do - for example, Dickens' Hard Times. For These Times - will always be borderline instances of literature or cinema. Propaganda is the most overt and explicit form of didacticism and thus likely to be the least artistic. Even if Triumph of the Will is primarily a work of art, or if a dual classification as art and propaganda is unproblematic, however, it is also a documentary of historical events. The fact that these events are both real and had horrific consequences presents a barrier to engaging with the work which distinguishes it from most other narrative artworks. In short, the film is a very poor example for any position in the debate.

\footnotetext{
85 "Art and Ethical Criticism," 380.

86 "Beauty and evil: the case of Leni Riefenstahl's Triumph of the Will," in Aesthetics and ethics: Essays at the intersection, ed. Jerrold Levinson (Cambridge: Cambridge University Press, 1998), 227-256: 237.
} 
If one is looking to cinematic art for examples, The Birth of a Nation seems a much better choice, but it has received very little attention thus far. ${ }^{87}$ Although the film involves a real organisation - the Ku Klux Klan - the events and characters depicted are fictional. The work is immoral in portraying the Klan as heroic defenders of liberty in the former Confederacy, but aesthetically valuable in its dramatic expansion of the horizons of the then (1915) fledgling art form. The problem with employing examples from film is that cinematic art is still in its infancy; if The Birth of the Nation was the first recognisably modern (albeit silent) film, ${ }^{88}$ the art form has only existed for less than a hundred years. As such, there is no accepted canon of great cinematic works which have stood the test of time to which Hume alludes in "Of The Standard of Taste". ${ }^{89}$ Canonicity is important because the debate concerns narrative art, and art is an evaluative as well as descriptive term. The discussion of works which do not qualify as art is unlikely to illuminate the relationship between morality and art. Membership of the canon of literature is a reliable guide as one can expect canonical works to be paradigmatic of literature.

I am not suggesting that the debate should be restricted to the discussion of literary examples, merely pointing out that cinematic examples are more likely to be subject to the quality objection I raise due to the lack of an established canon. While I agree with Kieran and Jacobson's concerns about the quantity of examples employed in the debate, the quality of these examples is also suspect because a significant proportion of the literary works discussed are extra-canonical. American $P s y c h o^{90}$ is a poorly-written morality tale. De Sade's oeuvre ${ }^{91}$

\footnotetext{
${ }^{87}$ Aaron Smuts ("Grounding Moralism: Moral Flaws and Aesthetic Properties," Journal of Aesthetic Education 45 [2011]: 34-53) is a notable exception. I discuss the film briefly in: [...].

${ }^{88}$ Similar moral concerns were raised about another candidate for this title, The Story of the Kelly Gang (1906). See: Sally Jackson \& Graham Shirley, "The Story of the Kelly Gang," The National Film and Sound Archive of Australia, October 2006, accessed 15 September, 2013, http://nfsa.gov.au/collection/film/story-kelly-gang/.

89 "Of the Standard of Taste," 233.

${ }^{90}$ Carroll, "Moderate Moralism"; Eaton, "Robust Immoralism".

${ }^{91}$ Gaut, "Ethical Criticism of Art" \& Art, Emotion and Ethics; Eaton, "Robust Immoralism".
} 
may have achieved respectability in consequence of the criticism of Guillaume Apollinaire, Simone de Beauvoir, Roland Barthes, and others, ${ }^{92}$ but his canonical status remains questionable when compared to contemporaries such as Goethe and Jane Austen. The place of Uncle Tom's Cabin ${ }^{93}$ in the canon is also disputable, as is J.G. Ballard's Crash. ${ }^{94}$ The problem with the focus on extra-canonical works is that it belies the fact that where examples are from the canon, their immorality is often far from clear. Lolita does not promote paedophilia any more than Paradise Lost promotes Satanism - quite simply, there is a paucity of examples of canonical works being morally reprehensible.

Several promising examples are not discussed in detail, and I suspect the reason for this is that they would provide evidence for the naivety of the debate rather than for one of the six perspectives. A more detailed consideration of any of the following would show that morality in narrative art is not as presented by the debate: the Iliad, ${ }^{95}$ The Merchant of Venice,${ }^{96}$ Wagner's Ring Cycle, ${ }^{97}$ the poetry of T.S. Eliot, ${ }^{98}$ and Ezra Pound's Cantos. ${ }^{99}$ The immorality in all these canonical works seems to be found in the assumptions made by their authors, the moral background of the works rather than any kind of explicit immoral prescription, prompting, or suggestion. A vast number of works in the literary canon were written in historical periods where the prevailing assumptions are now considered sexist and racist, and the immorality is often restricted to this moral framework. If one considers the canon, therefore, it appears that there are at least four relationships between morality and narrative art under discussion: prescription, prompting, suggestion, and assumption. The last

\footnotetext{
92 See, for example: Apollinaire's L'Oeuvre Du Marquis de Sade (Paris: Collection des Classiques Galants, 1909), de Beauvoir's Faut-il brûler Sade? (Paris: Gallimard, 1952), and Barthes' Sade, Fourier, Loyola (Paris: Éditions du Seuil, 1971).

${ }^{93}$ Jacobson, "Immoral Art"; Gaut "Ethical Criticism of Art" \& Art, Emotion and Ethics.

${ }^{94}$ Kieran, "Ethical Evaluation of Narrative Art".

95 Stecker, "Ethical and Aesthetic Value," 146-147.

${ }^{96}$ Anderson \& Dean, "Moderate Autonomism," 164-165.

${ }^{97}$ Gaut, "Ethical Criticism of Art," 182.

98 Ibid.

${ }^{99}$ Kieran, "Art, Imagination, and the Cultivation of Morals," 347.
} 
of these - which is clearly the most important where literature is concerned - has been largely ignored in the debate.

\section{The Underlying Issue}

I have identified the three most serious flaws in the value interaction debate as evidence that it offers a shallow analysis of the relationship between morality and art; I conclude with an acknowledgment and a recommendation. I focused on narrative art in order to demonstrate the naivety of the assumptions about the relationship between morality and literature (as well as cinema, with the reservation noted in $§ 5)$, and avoided commentary on other art forms. It could be argued that the assumptions I have labelled naive in the debate do not misrepresent the relation under discussion in non-narrative art. Thus, in Carroll's example of the painting of Hitler entitled Saviour, mentioned in §2, or Jacques-Louis David's The Death of Marat, it may be accurate to speak of the response the work prescribes, the attitude it prompts, or the moral perspective it suggests. The third term is too vague for my liking, but I would not dispute that both paintings invite one to regard their subject as a hero and his death as a tragedy. I may, therefore, be committed to the view that the relationship between morality and narrative art differs from the relationship between morality and non-narrative art. I see no reason why the two relationships should not differ, however, as the scope for moral complexity in narrative art seems much greater than that of non-narrative art. ${ }^{100}$

My recommendation is that philosophical attention be redirected from the superficial question of whether a moral defect is an aesthetic defect, to the following pair of questions: is there a characteristically artistic value, and - if so - is this value instrumentally or finally

${ }^{100}$ See fn. 7. 
valuable? Dominic McIver Lopes ${ }^{101}$ has recently generated a lively dispute ${ }^{102}$ by arguing that the characteristically artistic value can only be aesthetic value; if one takes this claim as a starting point, then the focus is on whether aesthetic value is a final or instrumental. ${ }^{103} \mathrm{I}$ have been entirely critical of Carroll thus far, but he has given this question one of its most comprehensive treatments in contemporary philosophical aesthetics. Carroll is emphatic both that art is not essentially aesthetic, and that aesthetic value is not final. His Art in Three Dimensions consists of twenty-six papers which share the following aim:

If Clive Bell, that arch-aesthetic theorist, advocated art as a means to escape the stream of life, it is the ambition of this book to plunge it once again back into the flow of our vital personal and cultural concerns. ${ }^{104}$

Carroll's conception of the characteristically artistic value combines both the aesthetic and the moral values of works of art. He claims that one of the strengths of his position is that his instrumental account of aesthetic value provides the simplest explanation of why those works of art which have aesthetic properties are valuable, and that there is thus no need to propose an extra - often intangible or obscure - value of art 'for its own sake'. ${ }^{105}$

Peter Lamarque takes up this challenge, employing the Death of Marat as a paradigmatic example in his durability argument for the final value of art:

The painting, whose initial usefulness was in propaganda for the Terror, became quickly discredited after the downfall and execution of Robespierre: painting and

\footnotetext{
101 "The Myth of (Non-Aesthetic) Artistic Value," The Philosophical Quarterly 61 (2011), 518-536.

102 Thus far: Stecker, “Artistic Value Defended," The Journal of Aesthetics and Art Criticism 70 (2012), 355362; Andrew Huddleston, “In Defense of Artistic Value,” The Philosophical Quarterly 62 (2012), 705-714; Louise Hanson, "The Reality of (Non-Aesthetic) Artistic Value," The Philosophical Quarterly 63 (2013), 493 508; Julian Dodd, “Artistic Value and Sentimental Value: A Reply to Robert Stecker," The Journal of Aesthetics and Art Criticism 71 (2013), 282-288; and Stecker, "Testing Artistic Value: A Reply to Dodd," The Journal of Aesthetics and Art Criticism 71 (2013), 288-289.

${ }^{103}$ For the purposes of this paper, I shall accept the equivalence of "non-instrumental" and "final".

104 “Art in Three Dimensions: An Introduction," in Art in Three Dimensions, (Oxford: Oxford University Press, 2012 [2010]), 1-16: 16.

105 “Aesthetic Experience: A Question of Content," in Art in Three Dimensions (Oxford: Oxford University Press, 2012 [2010]), 77-108: 95.
} 
artist alike became reviled and both were lucky to survive. The painting lay in obscurity for half a century. But gradually, from the mid-nineteenth century, interest in it revived. Baudelaire praised it as "David's masterpiece and one of the great treasures of modern art"; he spoke of its "drama" and "pitiful horror," adding "as cruel as nature, this picture has the heady scent of idealism." Now it is one of the most well-known and popular paintings of French neoclassicism. Art lovers flock to the Royal Museum of Art in Brussels to see it and pay homage to it. Its political usefulness has long expired. ${ }^{106}$

Lamarque's view is that while many great works of art initially have religious, moral, and political values - all of which are instrumental - these values tend to diminish as time passes. In contrast, however, the value qua art of those works which survive Hume's test of time not only endures, but increases. It is this durable value - aesthetic value in Lopes' terms - that the instrumental account cannot explain. Contra Carroll, aesthetic value cannot therefore be dispensed with, even if it is resistant to definition. ${ }^{107}$

The debate between Carroll and Lamarque - selected as exemplars of their respective positions - is of fundamental rather than superficial significance, and underlies (and undercuts) the value interaction debate. Carroll is committed to the view that a moral defect can also be an aesthetic defect because he maintains that the value of art qua art is not final or autonomous, but linked to its moral value. In contrast, although Lamarque has not contributed to the value interaction debate, he is committed to the view that a moral defect cannot be an aesthetic defect because art qua art is "useless", i.e. art has final or autonomous

\footnotetext{
106 “The Uselessness of Art," The Journal of Aesthetics and Art Criticism 68 (2010), 205-214: 211.

${ }^{107}$ I do not have space to discuss Lamarque's argument in detail and I employ it merely as an example of a response to Carroll. Other - to my mind less convincing - defences of the final value of art include: A.C. Bradley, "Poetry for Poetry's Sake," in A.C. Bradley, Oxford Lectures on Poetry (London: Macmillan, 1959 [1909]), 3-34; Monroe Beardsley, Aesthetics: Problems in the Philosophy of Criticism (New York: Harcourt, Brace \& World, 1958); Malcolm Budd, Values of Art (London: Penguin, 1995); and Richard Posner, "Against Ethical Criticism," Philosophy and Literature 21 (1997), 1-27.
} 
value (in addition to, and independent from, its instrumental values). The issue is not autonomism, one might say, but autonomy, and autonomism is one of several positions derived from the view that art has autonomous value. ${ }^{108}$ At present, there has been neither a response to Lamarque's durability argument nor a sustained critique of Carroll's Art in Three Dimensions. I believe that a reorientation of the discussion in this direction would provide a much more rewarding debate than the narrow concern with moral defects, as well as offering solutions to value interaction and other, related, problems. ${ }^{109}$

${ }^{108}$ Including debates over the relevance of the genetic and affective aspects of a work to its artistic value, and the debate about critical pluralism raised by Katherine Thomson-Jones ("Art, Ethics, and Critical Pluralism," Metaphilosophy 43 [2012], 275-293).

${ }^{109}$ I would like to thank Noël Carroll, Matthew Kieran, Peter Lamarque, Dimitris Platchias, and an anonymous referee from this journal for their invaluable assistance with this paper. 